\title{
Cesare Pavese, Italo Svevo ve Tezer Özlü'de İntihar Kavramı
}

\author{
BÜLENT AYYILDIZ*
}

\begin{abstract}
ÖZ
20. yüzyıl dünya ve İtalyan edebiyatının önemli isimlerinden olan Italo Svevo ve Cesare Pavese'de intihar kavramı önemli bir yer tutmaktadır. İntihar, hem Svevo'nun hem Pavese'nin yaratmış olduğu karakterlerin belirleyici ve önde gelen özelliklerinden biri olmuştur. Sadece psikolojik bir durum değil, aynı zamanda sosyolojik bir olgu olarak ele alınan intihar, birey ve toplum ilişkisinde ortaya çıkan çatlakların tanımlayıcı öğesi olmuştur. Svevo ve Pavese'nin ailevi ve toplumsal düzeyde yaşadıkları travmalar, eserlerinde yer verdikleri intihar kavramı ile koşutluklar gösterir. Bu iki yazara benzer bir şekilde, 20. yüzyıl Türk edebiyat1nın ikinci yarısında eser vermiş olan Tezer Özlüde de intihar ile ilgili benzer öğeler göze çarpmaktadır. Bu makalenin amacı, Svevo, Pavese ve Özlü’nün eserleri arasında var olan koşutlukları, özellikle intihar öğesinden yola çıkarak incelemek ve bu üç yazar arasındaki benzerlikleri ortaya çıkarmaktır.
\end{abstract}

Anahtar sözcükler: İntihar, İtalyan edebiyatı, Italo Svevo, Cesare $\mathrm{Pa}$ vese, Türk edebiyatı, Tezer Özlü

"Gerçekten önemli olan bir tek felsefe sorunu vardır, intihar."

Albert Camus

$\stackrel{\bullet}{\jmath}$

nsanlık tarihinin en önemli olgularından biridir intihar. En basit ifadelerle, kişinin kendi yaşamına bilinçli bir şekilde son verişini tanımlayan bu olgunun, İtalyan edebiyatında köklü bir geçmişi vardır; bu olgu karşımıza ilk olarak, 13. yüzyılda Dante'nin Divina Commedia (İlahi Komedya) adlı eserinde çıkar; Floransalı şair Dante, II. Federico'nun ${ }^{1}$ intihar eden danışmanı hukukçu ve şair

\footnotetext{
* Arş. Gör., Ankara Üniversitesi, İtalyan Dili ve Edebiyatı Anabilim Dalı/ANKARA E-posta: ayyildiz@ankara.edu.tr

1 II. Federico / II. Friedrich (Federico II. di Svevia): 1194-1250 yılları arasında yaşamış olan ve edebiyat ile sanata büyük önem veren Kutsal Roma Germen İmparatoru'dur. Hükümranlığ1 süresince sarayında Guido Bonatti, Leonardo Fibonacci, Michele Scoto, Giacomini da Lentini, Pietro Della Vigna ve Ja-
} 
Pietro Della Vigna'yı Divina Commedia adlı eserinin Cehennem adlı bölümünün 13. kantosunda, intihar edenler ormanına ${ }^{2}$ yerleştirir. 14. yüzyılda ise diğer bir önemli İtalyan yazar Boccaccio Decamerone adlı anıtsal eserinde pek çok aşk intiharını anlatır ${ }^{3}$ ve Floransa'da yaşanan kendini asma olaylarının sıklığından hayretle bahseder (Minios 2008: 76). 15. yüzyilda ise Il Cortigiano (Sarayli) adlı kitabın yazarı Baldassare Castiglione, saraydaki adab-1 muaşereti anlattığ1 eserinde Sagunto' $1 u^{4}$ kadınların intiharıly birlikte geçmişe ve o döneme ait pek çok intihar olayını hatırlatır (Minios 2008: 79). 18. yüzyıla gelindiğinde, ünlü trajedi yazarı Alfieri'nin pek çok eserinde; Foscolo'nun Ultime lettere di Jacopo Ortis (Jacopo Ortis' in Son Mektupları) adlı kitabında, Leopardi'nin ${ }^{5}$ Operette moralisinde (Ahlaki Operetler) intihar olgusu açıkça görülmektedir; hatta Leopardi'nin eserinde Plotino ve Parfirio'nun hikâyesi bu konuyu anlatırken, "İntihar" adlı ayrı bir bölüm bile bulunmaktadır. 19. ve 20. yüzyıllarda İtalyan edebiyatında, intihar olgusu sadece yazılan eserlerin bir ögesi olarak değil, aynı zamanda Gerolamo Rovetta, Francesco Gaeta, Emilio Salgari ve Pavese gibi yazarların hayatlarına son verme biçimi olarak da karşımıza çıkar.

20. yüzyıl İtalyan edebiyatının önemli isimlerinden Italo Svevo ve Pavese ile Cumhuriyet sonrası Türk edebiyatının değerli isimlerinden, 1986 yılında ölen Tezer Özlü'nün Çocukluğun Soğuk Geceleri ve Yaşamın Ucuna Yolculuk eserlerinde intihar öğesi önemli bir yer tutmaktadır. İntihar kavramının bu üç yazar ve onların eserleri bağlamında incelemeden önce, bu kavramın yapısına yakından bakmak oldukça yerinde olacaktır.

20. yüzyılın başlarında intihar ile ilgili çalışmalarda önemli gelişmeler yaşanmıştır. Özellikle yapılan otopsi sayılarının artması, intihar edenlerin istatistiki düzeyde takip edilmesi, intihar vakalarında fizyoloji ve nörolojik koşullar arasındaki bağlantıların ortaya çıkarılmasına yardımcı olmuştur. 1900’lü yılların başında, intihar, istatistiklerin ışığında öncelikle sosyal bir olgu olarak değerlendirilmeye başlanmış, ardından bireyin yaşamındaki rolü üzerine çeşitli incelemeler yapılmıştır (Evans, Farberow 2003: xxx).

copo da Lentini gibi pek çok sanatçı ve bilim adamını himaye etmiş, Ortaçağ’da sanatın ve edebiyatın gelişmesine oldukça büyük katkıları olmuştur.

2 İntihar edenler ormanı: İtalyan şari Dante'nin Divina Commedia (İlahi Komedya) adlı eserinin 13. kantosunda yer verdiği, intihar edenlerin karanlık bir ormanda ağaçlara dönüştürüldüğü ve ağaç dallarının Harypalar tarafindan sürekli parçalanarak sonsuz bir şekilde cezalandırıldığı bölümdür.

3 Örneğin, Boccaccio, Decamerone adlı eserinin dördüncü gününde "Filostrato" adlı dokuzuncu bölümde bir aşk intiharını anlatır.

4 Sagunto: İspanya’nın doğusunda, Valencia bölgesinde yer alan tarihi bir şehirdir.

5 Giacomo Leopardi: 1798-1837 yılları arasında yaşamış, İtalyảnın Recanati şehrinde doğmuş ve Napoli'de ölmüş, İtalyan Romantizminin en önemli temsilcilerinden bir filozof-şairdir. 
Konu ile ilgili öncü çalı̧̧malara imza atan Emile Durkheim da intiharı sadece bireysel değil, aynı zamanda toplumsal bir olay olarak incelemiştir. Fransız sosyolog ve düşünür Emile Durkheim, İntihar adlı eserinde, bu istemli eylemi şu şekilde tanımlar: "[Ö]len kişi tarafindan ölümle sonuçlanacağı bilinerek yapilan olumlu ya da olumsuz bir edimin doğrudan ya da dolaylı sonucu olan her ölüm olayına intihar denir" (Durkheim 1986: 4). Ancak Durkheim, kısa bir şekilde intihar tanımını yaptıktan sonra, bunun sadece basit bir şekilde tanımlanabilecek ve kısıtlanabilir bir olgu olmadığını, aksine farklı türleri ve çeşitleri olabileceğini söyler; bu çerçevede Svevo, Pavese ve Özlü’nün eserlerinde ve hayatlarında ruhsal durumlarını açıklayan iki farklı intihar fikrini tanımlar. Bunlardan ilki melankoli intiharıdır:

Melankoli intiharı: bu, hastanın çevresindeki insanlarla ve nesnelerle arasındaki ilişkileri sağlıklı olarak kavramasına olanak bırakmayan genel bir aşırı-bunalım ve yoğun üzüntü durumunda görülür. Hasta için artık zevklerin hiçbir çekiciliği kalmamıştır; her şeyi kapkara görür. Yaşam, ona sıkıcı ya da üzüntü verici gelmektedir. Bu duygular nasıl yerleşik bir hal almışsa intihar düşünceleri de öyledir; bunlar son derece sabit olup, kendilerine yol açan güdüler de her zaman esas olarak aynıdır. (Durkheim 1986: 24)

İkincisi ise saplantı (sabit fikir) intiharıdır. Durkheim'ın tanımlaması, sadece Svevo ve Pavese değil, Albert Camus, Franz Kafka, Stefan Zweig, Walter Benjamin gibi 20. yüzyıl yazarlarının pek çoğunda görülen ruhsal sorunları tanımlar niteliktedir:

Saplantı (sabit fikir) intiharı: bu durumda intihara yol açan şey ne gerçek, ne de hayali herhangi bir güdü değil, yalnızca herhangi belirli bir neden olmaksızın hastanın zihnini tamamıla etkisi altına almış olan ölüm saplantısıdır. Hasta, akla uygun hiçbir nedeni bulunmadığını kesinlikle bilmesine rağmen, kendi kendisini öldürmek arzusunu kafasından atamamaktadır. [...] hasta arzusunun saçmalığını bildiği için önce direnmeye çalışır. Ama bütün bu direnme boyunca üzgündür, bunalmaktadır ve göğüs boşluğunda her gün artan bir yürek sıkıntısı duymaktadır. Bu yüzden bu tür intihara kimi kez tasa intiharı adı verilmiştir. (Durkheim 1986: 25)

Durkheim'dan sonra intihar konusunda araştırmalar yapan diğer bir düşünür, aynı zamanda Durkheim'ın öğrencisi olmuş, Maurice Halbwachs'dır. Durkheim'ın teorisini özellikle, resmi istatistikleri kullanması ve toplumda var olan ilişkileri göz ardı etmesi yönünden eleştiride bulunur. Halbwachs, intihar olgusunun kişinin kendine zarar verme amacını taşıyan ve ölümle sonuçlanan her eylem için kullanılabileceği görüşündedir. Bu açıdan Halbwachs'in getirdiği yenilik toplumsal hafızayı ve birey-toplum ilişkisini gözeterek birey üzerine kurulu istatistiki sistemin eleştirilmesine dayanır (Evans, Farberow 2003: xxx). 
Durkheim ve Halbwachs'ın yanı sıra, insan psikoloji ve intihar söz konusu olduğunda, değinilmeden geçilemeyecek en önemli düşünürlerden biri de kuşkusuz Sigmund Freud'dur. İnsanın bilinci ve bilinçaltı ile ilgili detaylı çalı̧̧malar yapan, insan psikolojisini anlamaya yönelik getirdiği kuram ve yaklaşımlarla bilime büyük katkı sağlamış, insanın ayrılmaz bir parçası olan ölüm korkusu ve intihar olgusu ile ilgili de çalı̧̧malar yapmıştır. İntihara ilişkin ilk çalı̧malarını Yas ve Melankoli adlı makalesinde ortaya koyan Freud, bu olgunun iki farklı temel duruma dayandığını vurgular. Freud'a göre intihar ya çok sevilen bir nesnenin kaybından ya da çok sevilen bir nesneye ulaşamamasından doğan aşırı düş kırıklığından kaynaklanır (Evans, Farberow 2003: xxxi). İntiharın yapısındaki bu dalgalanmaları ve zıt noktaları sözü geçen makalesinde şu şekilde açıklar:

Melankoliyi bunca ilginç ve tehlikeli kılan intihar eğilimi bilmecesini tek başına çözen bu sadizmdir. Egonun, dürtüsel yaşamın doğup geliştiği ilkel durumu olarak bildiğimiz kedine yönelik sevgisi o denli büyük ve yaşama yönelik bir tehdit karşısında olağan korkunun içinde açı̆̆a çıkan narsisistik libidonun miktarı o denli fazladır ki, egonun kendi yıkımına nasıl razı olabildiğini anlamak mümkün değildir. [...] Bugün melankolinin analizi egonun ancak dış dünyadaki nesnelere özgün tepkisini simgeleyen ve bir nesne ile ilgili olan düşmanlı̆̆ını kendine yöneltmesi, kısacası nesne-yaratımına dönerek kendine bir nesne gibi davranması durumunda kendini öldürebileceğini göstermektedir. (Freud 1993: 4)

Daha sonraları bu fikirlerini geliştiren Freud 1922 yılında yayınladığı Beyond The Pleasure Principle adlı çalışmasında, intihar kavramını ölüm içgüdüsünü temel alarak açılar: Her insanın özünde iki farklı içgüdü mevcuttur, birisi yaşama içgüdüsü olarak adlandırılabilecek olan Eros, diğeri ise ölüm içgüdüsüne karşıllk gelen Thanatos'tur. Bu iki içgüdü her bir insanın hayatında birbirleriyle mütemadiyen bir çatı̧̧ma içerisindedirler (Evans, Farberow 2003: xxxi).

Yoğun ve aşırı stres ya da duygusal düzensizlik/bozukluk anında, daha ilkel olan ego durumu, diğer bir deyişle Thanatos, açığa çıkar ve insanın kendine zarar verme şansı fark edilebilir bir şekilde yükselir. Bu yaklaşım ile Freud, intiharı insanın en temel içgüdülerinden biri sayarken aynı zamanda onu şiddet ve saldırı eylemleri ile de pekiştirir (Barry 2002: 102). Zira bu şiddet ve saldırı olasılığı, intihar olgusuna Freud'un getirdiği bir yeniliktir. Kendinden önceki çalışmacılar intihar olgusunu istatiksel ve toplumsal yönü ile ele alırken, intiharın oluş şeklini ve saldırıyı göz ardı ederken sadece sonuca odaklanmış bulunmaktaydilar.

İntihar kuramı ile ilgili çalışmalar yapan ve bu kuramın gelişmesine yardımc1 olan kişilerin başında Karl Menninger gelmektedir. Alana katkıları sadece yazdığı makale ve kitaplarla sınırlı değildir, aynı zamanda açmış olduğu klinik 
ile de intihar ile ilgili çalışmaların artmasına ve kavramın olgunlaşmasına katkıda bulunmuştur. İntihar kavramını, kendinden önce gelen düşünürlerden çok daha geniş bir bakış açısı ile ele alan Menninger, intiharı kendine zarar verme ve saldırganlık fikirlerinden yola çıkarak tanımlar. "İntihar, kurbanın katil olduğu ve öldürüldüğü, öldürme eylemidir” (aktaran Mellor 1979: 182) şeklinde görünürde basit ama içerik olarak yoğun tanımlama yaparak intiharı oluşturan üç temel öğeyi açıklar: öldürme arzusu, öldürülme arzusu ve ölüm arzusu.

Sigmund Freud'un şiddet ve saldırganlık temalarını genişleten Menninger, intiharı kurban ve bilinç eksenine oturtur ve kendine hasar verme, ölüm içgüdüsü ile yaşam içgüdüsü arasındaki ilişki ile bağdaştırarak anlatır. Menninger'in kavrama getirdiği yenilik, "sürekli/kronik intihar" olarak adlandırdığı olgudur. Menninger, kişinin kendisine yönelik saldırganlık ve şiddet eylemlerinin sonucundan yola çıkarak, intihar kavramını açıklar. Ölümle sonuçlanmayan her bir şiddet eylemini sürekli/kronik intihar kavramının bir parçası olarak görür ve intiharı da bu kronik çabaların son basamağı olarak değerlendirir (Evans, Farberow 2003: xxx). Görüldüğü gibi Menninger için, intihar bir anlık fevri ve patlayıcı bir olgu olmaktan ziyade, bir süreç, devam eden bir psikoz durumudur. Bu açıdan bakıldığında, edebiyat insanlarında var olan ölüm ve intihar takıntısını açıklayan oldukça önemli bir kuram sunmaktadır.

İntihar ile ilgili çalışmaları diğer araştırmacılara göre, görece az olan Carl Gustav Jung, kavramın gelişimine önemli katkı veren diğer bir isimdir. Jung kendinden önce ortaya atılmı̧ olan intihar fikirlerini kabul etmekle birlikte, olgunun çıkış noktası olarak, bir kaçış arzusunu görür. Jung için intihar bugünün tahammül edilemez ve başa çıkılamaz koşullarından bir kaçış, bir çıkış yoludur (Evans, Farberow 2003: xxxi). Şüphesiz ki, Jung'un geliştirdiği bu yaklaşımda, II. Dünya Savaşı sonrası düşün dünyasında oldukça etkili olan daha iyi bir hayata, daha iyi bir geleceğe ve daha iyi bir dünyaya sahip olma arzusu ve özlemi yatmaktadır.

Konu ile ilgilenen bir başka araştırmacı ise Thomas G. Masaryk'tır. Yazar, Suicide and The Meaning of Civiliazition adlı çalışmasında, intihar olgusunun ortaya çıkışının belirlenmesinin oldukça zor olduğunu söyler. Zira intiharı oluşturan nedenlerin insanın hem biyolojik hem de sosyal yapısı ile ilgili olduğu fikrini savunur. Masaryk'e göre, intihar sadece zihinsel hastalık ile açıklanamaz, bunun yanı sıra bireyin sosyal ve ahlaki yapısının, bu yapıda meydana gelen bozuklukların da göz önünde bulundurulması gerektiği fikrini savunur (Evans, Farberow 2003: xxix).

Tüm bu araştırmacıların fikirleri göz önüne alındığında, intihar, 20. yüzyıl itibarıyla hem toplumsal bir gerçekliğin hem de bireysel bir durumun anlatımı konumuna yükselir. Daha önceleri, sadece bir tür ölüm çeşidi olarak ele alınan kavram, 20. yüzyıl ile birlikte, geniş ve incelikli bir çalışma alanına dönüş- 
müştür. Bu dönüşümde etkili olan en önemli faktör, dünyadaki sosyal, politik, ticari ve kültürel yapıların hızlı bir şekilde değişime uğramasıdır. Sanayi devrimi ile birlikte, 19. yüzyıldan itibaren birey hem edebiyatta hem hayatta, başlı başına bir değer olarak ortaya çıkmaya başlamıştır. Bireyin önem kazanmaya başlaması, hem psikolojik hem sosyolojik eylemlerin incelenmesini zorunlu hale getirmiştir. Zira toplumun temel taşı olan birey, bütünü anlama yolunda bir başlangıç noktasına dönüşmüştür. Bu çerçevede, $\mathrm{G}$. Lukacs roman kuramını oluştururken birey ve çevresi arasında var olan ilişkiye oldukça önem vermiş, dış dünya ile romanın dünyasının sıkı sıkıya birbirlerine bağlı olduklarını savunmuştur:

Romanın dış biçimi özünde biyografiktir. Bir yanda hayatı asla tümüyle kavrayamayan bir kavramsal sistem ile öte yanda tamamlanmışlık içkin biçimde ütopik olduğu için asla böyle bir tamamlanmışlı̆̆a ulaşamayan bir hayat karmaşası arasındaki gidiş geliş, ancak biyografinin hedeflediği organik nitelikte nesnelleştirilebilir. (2011: 83)

Pavese ve Svevo'nun Tra donne sole (Yalnız Kadınlar Arasında) ve Una vita (Bir Hayat) eserlerinde yer verdikleri karakterler -Rosetta ile Alfonso- bu yönden ele alındıklarında aslında yazarlarının aynası, hatta sosyolojik yans1malarıdırlar. Pavese ve Svevo'nun yaşamlarını yansıtan bu karakterler, bireysel ve sorunsal olmalarının ötesinde, büyük tablonun, diğer bir ifadeyle ekonomik çıkarlar tarafından kuşatılmış ve I. Dünya Savaşı'nın sorunlu dünyasının küçük ölçekli birer kopyası niteliğindedirler.

Hem Pavese, hem de Svevo dünya savaşlarının yıkıcılığına tanık olmuşlar, ardından yaşanan toplumsal bunalımın ve çöküşün de izlerini eserlerine yansıtmışlardır. Bu yansıtmaların konusunu oluşturan olgunun çıkış noktası ile ilgili olarak, II. Dünya Savaşı döneminin ünlü Fransız düşünür ve yazarı Albert Camus, "Savaş yadsınamaz. Ondan ölmek ya da onunla yaşamak gerekir" (1997: 111) diye yazar ve insanoğlu için bir yandan savaşın kaçınılmazlığını anlatırken, diğer yandan da acımasızlığını vurgular.

Una vita'da Alfonso Nitti, Tra donne sole'de Rosetta ve Çocukluğun Soğuk Geceleri ile Yaşamın Ucuna Yolculuk'ta Özlü karakterleri kendi iç sıkıntıları aracalığıyla aslında varoluşun ve insan yaşamının anlamsızlığının sorunlarıyla boğuşmaktadırlar. Karakterler ve içinde yaşadıkları dünyaları arasındaki bu sıkı ilişkiyi Lukacs aşağıdaki gibi açıklar: "Bir biyografinin merkezi karakteri ancak kendisinden daha büyük bir idealler dünyasıyla olan ilişkisi nedeniyle önemlidir; bu dünya da, ancak o bireyin yaşanmış deneyimi aracılığıyla kavranır" (2011: 84).

Bu yaklaşımla, Lukacs bireyi, toplumu oluşturan parçaların temeli olarak görmekte ve bireyin kişilik yapısının -psikolojisinin- toplumsal normların küçük bir kopyası olduğu görüşünü öne sürmektedir: “ [...] ama bireyi kuşatan dün- 
ya, bireyin iç dünyasının da dayandığı ve yalnızca içerik bakımından farklılaştığı aynı kategorik biçimlerin alt-yapısı ve malzemesidir” (2011: 85). Bireyi bu yönüyle ele almak, onu basit bir özne konumundan ayrıştırarak, nesne konumuna dönüştürmektedir. Bireyin özneleşen ve nesneleşen yapısı gelgitli bir ikilem oluşturur. Svevo, Pavese ve Özlü’nün eserlerinde yaşama devam etme arzusu ve intihar isteği arasında görülen de benzer bir ikilemdir.

\section{Svevo'da İntihar Olgusu ve Una vita Adlı Eseri}

20. yüzyıl İtalyan ve dünya edebiyatının en önemli figürlerinden biri olan Svevo (Ettore Schmitz) 1861 yılında Trieste'de dünyaya gelir ve 1928 yılında aynı şehirde hayata gözlerini yumar. İtalya'nın kuzey bölgesinde yer alan Trieste şehri, kozmopolit yapısıyla ön plana çıkar: şehir tarihi boyunca İtalyanlar, Avusturyalılar, Yugoslavlar ve Almanların egemenliği altına girmiş, bunun sonucunda pek çok farklı kültürün etkisinde kalmıştır. Şehrin coğrafi konumu ve yapısı yerel özelliklerin korunmasına, özelde Avrupa, genelde ise tüm dünya ile sıkı bağların kurulmasına olanak sağlamıştır. Trieste, 19. ve 20. yüzyıllarda, Svevo başta olmak üzere, Umberto Saba, James Joyce, Stendhal, R. M. Rilke, Ivo Andric ve Susanna Tamarro gibi pek çok edebiyat ve düşün insanına ev sahipliği yapmıştır. Bu isimleri telaffuz etmek bile Trieste'nin İtalyan, Fransız, Alman ve Avusturya düşünce yapıları ile yoğrulmuş, çok uluslu ve çok kültürlü bir yapıda olduğuna işaret eder. Svevo, işte bu kültürün etkisiyle edebiyat anlayışını geliştirmiş ve eserler vermiştir.

Daha çok yazmış olduğu La coscienza di Zeno (Zeno'nun Bilinci) adlı eserle tanınan Svevo, dönemin edebiyat anlayışına büyük bir yenilik getirmiştir: psikanalizi ve bununla beraber insan psikolojisini edebiyatla harmanlayan yazar, James Joyce başta olmak üzere, pek çok Avrupalı edebiyatçıya ilham vermiştir. $\mathrm{Bu}$ edebiyat-psikoloji ilişkisini geliştirmesinde Sigmund Freud'un etkisi oldukça fazladır: Freud'un psikanaliz ve bireyin toplumla olan ilişkisi hakkındaki düşünceleri Svevo'yu derinden etkilemiştir. Sigmund Freud'un Svevo'yu etkilemesi kadar, Trieste şehri de Freud'u etkilemiştir: ünlü Alman düşünür ilki 1876 yılında, diğerleri 1895 ve 1904 yıllarında olmak üzere toplam üç kez üzerinde büyük etkisini hissettiği Trieste'ye gitmiştir.

Svevo'nun Una vita adlı eseri ilk olarak Wram yayınevince, baskı masrafları yazarı tarafindan karşılanmak suretiyle, 1892 y1lında Trieste'de $U n$ inetto (Bir Uyumsuz) başlı̆̆ıyla yayınlandı: eser, otobiyografik öğelerden yola çıkan ve intihar ile sonuçlanan bir varoluşun hikâyesidir. Ancak eserin ismi daha sonra ticari kaygılardan dolayı değiştirildi ve Una vita adıyla tekrar yayınlandı. Una vita, Alfonso Nitti adlı bir gencin bankada çalışmak üzere taşradan şehre gelişini ve Nitti'nin yaşadıklarını anlatır. Nitti, çift yönlü bir hayat sürer: bir yanda içinde yaşamını sürdürdüğü kent soylu toplumun gereklerini yerine getirmeye 
çalı̧̧an bir banka memuru; diğer yanda ise edebiyat çalı̧̧malarına ve hayallerine dalmış bir genç vardır. Alfonso Nitti, kent soylu sınıfın yeni bir üyesi olarak, bu sınıfın sağlamış olduğu inançlara, geleneklere ve alıskanlıklara uyum sağlayamaz (Salinari ve Ricci 1993: 273, 274). Başladığı yeni işi ve yaşadığ1 uyumsuzluğu şu cümlelerden anlamak mümkündür:

Yorgunluk? Daha çok bir bulantıya benziyordu. Yavaşça, günden güne işi artmaktayd, ama işin niteliği ya çok az değişiyor ya da hiç değişmiyordu. Tüm bir gün boyunca bir ya da iki defagün sonu hesap işlemi yapmaliydi; kopya edilecek binlerce sayı ve tekrar tekrar yazılması gereken hep aynı cümle vardı oysa: akşama doğru eli, vücudunun gerçekten yordun olan tek uzvu, duruyordu, dikkati uyarılmadığ 1 sürece dağılmaktaydı ve tek bir besinden aşırı derecede tüketmiş biri gibi bulantı nedeniyle bazı seferler kalemi elinden atmak ve işi bırakmak zorunda kaliyordu. (Svevo 2010: 83)

Svevo, Una vita'dan itibaren, Emile Zola'nın ve Goncourt kardeşlerin gerçekçi ve psikolojik edebiyat yaklaşımlarını benimsemiştir (Pazzaglia 1988: 876); bu yaklaşımları kendi deneyimi ve Trieste şehrinin gelişmesine katkıda bulunduğu çok kültürlü kişilik yapısı ile harmanlayarak, özgün karakterler yaratmayı başarmıştır. Svevo'nun yaratmış olduğu karakterlerin temel özelliği, ne başkaları gibi yaşamayı ne de başkalarıla geçinebilmeyi başarmalarıdır.

I. Dünya Savaşı gibi sosyal ve psikolojik açıdan yıpratıcı ve yıkıcı olan büyük bir olayı yaşayan Svevo'da, henüz edebi yaşamının başındayken, intihar olgusu belirleyici bir nitelik taşır: Una vita adlı eserinde ana karakter Alfonso Nitti, içinde doğduğu taşra hayatını terk ederek, büyük hayallerin peşinden şehre gelerek bankada çalışmaya başlayan saf ve içine kapanık bir gençtir. Alfonso'nun büyük hayaller olarak nitelediği şey: iyi bir iş ile kendisine uygun bir eş bulmak ve iyi bir sosyal statü sahibi olmak. Bu büyük amaçların peşinde koşan Nitti'nin taşralı yanı, bu içine yeni yeni girmeye başladığı şehir hayatına ve sanayi devriminin yarattığı hızlı değişimlerin şekil verdiği topluma uyum sağlayamaz. Nitti'nin yaşadığı zihinsel bunalımı ve fiziksel yıpranmayı dışarıdan bakan bir gözle Svevo şu şekilde dile getirmektedir:

Alfonso şehre, orada yaşayanlar için beslediği büyük bir küçümseme ile gelmişti; onun için şehirli olmak fiziksel olarak zayıf ve ahlaki açıdan çökmüş olmaya eşdeğerdi;, ve şehirli insanların cinsel alışkanlıklarını, genel olarak kadınlara duydukları aşkı ve aşkın kolaylığını küçümsüyordu. Onlara benzemeyeceğine inanıyor ve o an için onlardan çok daha farklı olduğunu hissediyordu. Duygunun yüceltilmesindeki duygusallığ1 bilmiyordu. (2010: 88)

$\mathrm{Bu}$ noktada Svevo'nun Alfonso Nitti ile ötekiler arasında bir ayırım yaptığı, aslında birbirlerinden çok farklı olan bu yapıların bir araya gelmelerindeki zorlukları anlattığı açıkça görülmektedir. Nitti, içinde yaşadığı topluluğun bir parçası olarak görmez ve farklı olduğu için gizli bir gurur duyar. 
Her ne kadar kendini toplumdan ve diğer bireylerden farklı görse de, hayallerinden vazgeçmeyen Nitti, kendi kurtuluşuna zengin bir kadınla evlenerek ulaşmaya çalı̧ır: Çalıştı̆̆ı bankanın sahibinin kızıyla evlenen Nitti, doğrudan bir bağ ile burjuva toplumunun bir parçası haline gelir. Fakat bu ani yükseliş Nitti'nin başını döndürür, istediği yaşamın bu olmadığına kanaat getiren Nitti kendini edebiyat ile sanat çalışmalarına vererek, varoluşuna bir anlam katmaya çalışır. Ancak beceremez ve hikâyenin sonunda intihar eder.

I. ve II. Dünya Savaşı gibi psikolojik açıdan önemli yıpratıcı olaylarla karşı karşıya kalan yazar ve şairlerde intihar, ölüm, daha genel bir ifade ile "travma" oldukça yaygındır. Savaşın acımasızlığı ile getirdiği ruhsal ve toplumsal parçalanma, iyi bir geleceğe, hatta herhangi bir gelecek olabileceğine dair inançların yitirilmesi, pek çok yazar ve şairi bir kaçış aramaya itmiş, intihar etmesine neden olmuştur. Bu duruma örnek olarak Walter Benjamin ve Stefan Zweig verilebilir. Savaşın yarattığı zorlukların sosyal yaşama yansıması bir tür sakınıma bağlı olarak travma olgusunu tetikler. Bu yönüyle, Svevo'nun Una vita adlı eserinde Alfonso Nitti karakteri incelendiğinde, travma yaşayan yazarlarla benzer yönelimler göze çarpmaktadır.

19. ve 20. yüzyıllar arasında bir geçiş dönemi yazarı olan Triesteli Svevo Una vita adlı eserinde dekadant Avrupa'nın bir temsilcisi niteliğinde olan Alfonso Nitti'nin kimlik arayışını ve hayatına bir anlam verme çabasını yansıtır. Çökmekte olan bir uygarlığın -Avrupa Uygarlığı'nın- bir bireyi olan Nitti'nin içsel bunalımlarını aktarır. Alfonso Nitti, yaşadığı içsel bunalımlardan hiç bir şekilde kendini kurtaramaz, çünkü yenilgisinin sebebi, kaderin ya da hayatın acımasızlığı ile değil, kendi benliği ile ilintilidir (Petronio 2000: 16).

Una vita Alfonso Nitti'nin kendini öldürmesiyle son bulur. Svevo, intiharı, genel olarak ise ölümü, içinde yaşadığımız dünyanın getirdiği acılardan ve s1kıntılardan bir kaçış, bir nevi çıkış yolu olarak görür ve içinde geçmişe özlemle birlikte bir nebze de olsa umut barındırmaktadır:

Federico Maller ile her türlü avantajın rakipte olduğu bir mücadeleye girmek zorundaydı: nefret ve yetenek. Ne umabilirdi ki? Acınası ve komik tarafinı oluşturacağı bu mücadeleden kaçmak üzere kendisine sadece tek bir çıkar yol kalmaktaydı: intihar. İntihar belki de Anetta'nın şefkatini ona geri getirebilecekti. (2010: 487)

Svevo'nun Una vita adlı eserinde başkahraman Alfonso Nitti'nin ismi, romanın ilerleyişi ve yapısı hakkında önemli bilgiler verir. Alfonso'nun soyadı "Nitti” karakterin varlığının anlamsızlı̆ına vurgu yapar. Zira "nitti” sözcüğü İtalyanca "inetto" sözcüğünden türetilmiş bir sözcük oyunu barındırmaktadır: "inetto" "beceriksiz, yetersiz, etrafına uyum sağlayamayan" anlamlarına gelmektir. Bu ifadeler ise Alfonso'nun romandaki konumunu yansitmaktadırlar. Söz konusu olan, bankadaki işinde beceriksiz, eşiyle ilişkisinde yetersiz, dünya 
ile olan ilişkisinde ise uyumsuz olan bir adamın hikâyesidir: "O ise kendini hayata karşı uyumsuz hissediyordu. Sıklıkla faydasız bir şekilde anlamaya çalı̧̧tı̆̆ bazı şeyler ona acı vermekte, dayanılmaz hale gelmekteydiler. Ne sevmeyi biliyordu ne keyif almay1 [...]" (Svevo 2010: 384).

Ayrıca, Lukacs'ın roman kuramında belirttiği üzere, roman karakterleri ve romanların yazarları arasında sıkı bir ilişki mevcuttur. Diğer bir deyişle romanlar temelde yazarların özyaşamöyküsel özelliklerini de barındırmaktadırlar. Bu yorumu kanıtlar nitelikte, Una vita’nın Alfonso Nitti'si ile Svevo arasında oldukça belirgin bağlar bulunmaktadır: Svevo da Nitti gibi bankacılıkla uğraşmıştır, Svevo ile Nitti’nin doğum yılları aynıdır (1861), tıpkı Nitti gibi Svevo da iş nedeniyle sıkıntıya düştüğünde ve bunaldığında, kütüphaneyi bir sığınak olarak görmüş ve çareyi kendini edebi ve zihinsel çalışmalara adamakta bulmuştur.

Svevo'ya göre toplum, hatta dünya, sağlam, daimi ve kusursuz mahiyette temeller üzerine kurulmuş gibi görünmektedir. Birey ise böylesine yapay ve aldatıcı bir toplumda, seçim özgürlüğüne sahip olduğu ve geleceğini bu seçimlere göre şekillendireceği inancındadır. Ancak, bireyin seçimine ve dolayısıyla geleceğine yön veren, toplumdur: Bu nedenledir ki kendi kararlarını almada yetersiz kalan Alfonso Nitti, hayatın getirdiği zorluklara katlanamaz ve intihar eder: "Bu sükûnet nedir bilmeyen organizmayı yok etmek gerekmekteydi; canlı kaldığı müddetçe onu mücadeleye çekmeye devam edecekti zira bu amaçla yaratılmıştı" (Svevo 2010: 384).

\section{Pavese ve İntihar Olgusu}

I. Dünya Savaşı sonrası İtalya’sının, yazdığı romanlar, öyküler, şiirler ve yapmiş olduğu çeviriler ile en önemli entelektüel figürlerinden biri olan Pavese 1908 yilında dünyaya gelir ve 1950 yilında intihar ederek yaşamına son verir. Pavese'nin çocuk yaşta babasını kaybetmesi, İtalya'da bulunan kasvetli Torino şehri, ablasının hastalığ1 ve tüm ailenin yükünü sırtlamak zorunda kalan annesinin despot karakteri ile olan uyumsuz ve olumsuz ilişkisi, şairin kişiliğinde derin iz bırakan olgulardır (Balamir 2013: 253). Pavese'nin poetikasının temelinde, çocukluğun tekrar keşfi yatmaktadır. Çocukluk çağını, Pavese, kişinin temel deneyimlerini edindiği çağ olarak tanımlar. Çocukluk çağında, kişi dünya ile ilk temaslarını gerçekleştirir ve bilincinde yer edinen her bir kavram, nesne, duygu ve düşünceye bağlı olarak semboller ve mitler üretir (Balamir 2013: 253). Yalnızlık günlerinde tek bir düşünce ile avunur: intihar. Zihnini ve bedenini ironik bir şekilde zinde tutan bu düşünce ile ilgili olarak Il mestiere di vivere (Yaşama Uğraşı) adlı günlüğünün ilk bölümünde şöyle yazar: “[...] şunu öğrenir insan: uçurumdan kurtulmanın tek yolu ona bakmak, derinliğini ölçmek ve kendini o boşluğa bırakmaktır” (Pavese 1973: 43). 
Yukarıda bahsedilen olguların her biri Cesare Pavese'nin yazınsal üslubunu etkileyen ögelerdir. Torino bölgesinin intihar olgusuna önemli bir katkısı vardır. Zira Emile Durkheim'a göre intihar oranı üzerinde etkili olduğu, a priori, düşünülebilecek iki tür toplum dışı etken vardır: bunlar ruhsal eğilimler ile fiziksel ortamın niteliğidir. Pavese'de de fiziksel ortamın şairi sürüklediği bunalım açıkça göze çarpmaktadır. II. Dünya Savaşı sonrası İtalyan edebiyatının önemli yazar ve eleştirmenlerinden olan Italo Calvino, Pavese ile ilgili olarak yazmış olduğu denemesinde şu ifadelere yer verir:

Doğduğu aşağı Piemonte'nin tepelik bölgesi 'Langa' yalnızca şaraplar1 ve mantarlarılya değil, aynı zamanda köylü ailelerin salgın halinde tutuldukları umutsuz bunalımlarıla da ünlüdür. Diyebiliriz ki, hemen her hafta Torino gazetelerinde, kendini asan ya da kendini hayvanları ve aileleri de içindeyken çiftlik evini ateşe veren bir çiftçi haberi yer alır. (2008: 283)

Calvino'nun bu saptaması, Pavese'nin La luna e i falòda (Ay ve Şenlik Ateşleri) adlı eserinde kendini açıkça gösterir. Eserdeki karakterlerden Valino'nun bir sinir krizi geçirerek Rosina'yı dövmesini, evi ateşe vererek Rosina ile birlikte yaşlı nineyi öldürmesini ve ardından intihar etmesini şu şekilde anlatır:

[...] elinde camı çıkartılmış lambayla dışarı çıkmış. Koşarak evin çevresini dönmüş. Samanları, otları tutuşturup lambayı pencereye firlatmış. Dayak atılan oda alevler içinde kalmış. Kadınlar dışarı çıkmamışlar; Cinto, onların ağlayıp bağırdıklarını duyar gibi olmuş. [...] tavşanlar kaçışışlar. Öküz de yanmış ahırda. [...] Valino elinde bir iple bağa koşmuş, Cinto’yu aramak için. Cinto elindeki bıçağı sıkarak derenin kıyısına kaçmış. [...] Cinto köpeğin sesini de, başka hiçbir sesi de işitmez olunca bir uykudan uyandığını sanmış, orada ne işi olduğunu anlayamamış. Sonra bıçağı elinde sıkarak yavaş yavaş ceviz ağacına doğru çıkmıs, alevlerin çıtırtısını, görüntüsünü arayarak. Ve ceviz dallarının kemerinin altında babasının (Valino'nun) ayaklarının sallanmakta olduğunu görmüş, merdiven de yerdeymiş. (1997: 130)

Karamsar ve kasvetli Torino şehri sadece Pavese'de değil, Türk yazar Özlü'de benzer bir etki yaratır: Özlü ilk önce Almanca olarak yazdığı, 1982 yılında Almanya'da Auf den Spuren Eines Selbstmords (Bir İntiharın İzinde) adıla ve ardından 1984 yılında Türkçede yazarın kendi çevirisiyle Yaşamın Ucuna Yolculuk adıyla yayınlanan eserinde, Pavese'nin intihar ettiği Torino şehrine seyahatini anlatır: bu seyahat sırasında Torino şehri ile bu şehrin yaratmış olduğu karamsarlık hakkında şu satırları yazar:

Hayır. Hayır. Bu kent yanlış yere kurulu. Bu kentin nehir kıyısında ve tepelere doğru yükselerek yer alması gerekirdi. Hiçbir kentin Torino kadar intiharı düşündüren, insanı intihara iten bir mimarisi olamaz. Yok. Dağlara kapalı. Po nehrine kapalı. Güneşe kapalı. Gökyüzüne kapalı. Y1ldizlara kapalı. Esintilere kapalı. (2005: 124) 
La luna e i falò, Pavese'nin yazmı̧̧ olduğu son kitap olmanın yanı sıra, özyaşamöyküsel nitelikler taşımasıyla da oldukça önemlidir. Pavese eseri kaleme alırken, son eserini yazdığının farkındadır: bu nedenle tüm yaşam ve edebiyat deneyimini anlatma isteği duyar. Pavese'nin poetikasının temel niteliklerinden biri olan geçmişe özlem ve çocukluğa dönüş olgusu, bu eserde oldukça belirgindir. Ancak, bu sadece basit bir özlem duygusu değil, aslında Pavese'nin ait olduğu kökenleri arama yolculuğudur (Manacora 1977: 373).

Pavese'nin günlüğünde yazdıkları ve eserlerine yansıttıkları Emile Durkheim'ın savunduğu şekliyle benzerlikler gösteren takıntılı bir tutumun göstergesidir. Pavese intihar için şunları yazar:

Ancak böyle açıklayabilirim içimde duyduğum intihar dürtüsünü. $\mathrm{Ne}$ zaman bir güçlükle ya da acıyla karşlaşsam, hep intiharı düşünmeye yargilı olduğumu biliyorum. Beni korkutan da bu: temel ilkem intihar, gerçekleştiremediğim, hiç bir zaman gerçekleştiremiyeceğim, ama düşüncesi duyarlığımı okşayan intihar. (1973: 36)

Pavese'nin intihara yaklaşması ilk olarak, lise yıllarında zatürreye yakalanıp üç ay boyunca evde kapalı kaldığı, karanlığı ve geceyi sevmeye başladığı hastalık döneminde başlar. Bu dönemde, kendiyle konuşan, çevresi ile iletişimi iyi olmayan, San Stefano'nun ağaçları, doğası ve caddeleri ile konuşan Pavese, yalnızlığa düşkün hale gelmeye başlamıştır. 1926 yılında bir okul arkadaşının intiharı Pavese'yi derinden etkiler. 1927 yılının başlarında kendisi de intiharı dener, ancak başarılı olamaz. Yazarın intihar düşüncesi ile ikinci kez avunmaya başladığı dönem ise 1935 yılında, politik eylemler ve fikirleri dolayısıyla üç yıl hapse mahkûm edildiği ve Brancaleone'ye ${ }^{6}$ sürüldüğü zamana rastlar (Balamir 2013: 254). "İntiharı düşünen bir insan için en kötü şey kendini öldürmesi değil, bunu düşünüp yapamamasıdır. İntihar düşüncesine - bir alışkanlık haline gelen intihar düşüncesine - yol açan manevi çöküntü kadar aşağılık bir şey yoktur" (Pavese 1973: 53).

İkinci bir defa intiharda avuntu bulması, Pavese'de tekrar tekrar beliren, diğer bir deyişle saplantıya dönüşmüş "intihar" olgusunun yansımasıdır. Ancak aynı zamanda Menninger'in belirttiği kronik intihar düşüncesinden de izler taşır. Zira Pavese, intiharı sadece düşünce olarak değil, fiziksel olarak da deneyimlemiş ve kendisine bilinçli olarak zarar vermeye çalışıştır ve bu çabalarını uzun bir süre sonra nihayete erdirebilmiştir. Bir yazarın, hassas yaradılışlı bir kişinin, ruh halini en iyi anlayabilecek kişi, başka bir yazardır: Pavese ile aynı dönemde yaşamış, aynı sorunlarla boğuşmuş, benzer bir şekilde hayatı sorgulama içinde olan Albert Camus, Pavese'de ilk gençlik yıllarından başlayan bu saplantılı düşünceyi, intiharı, şu şekilde açıklar:

Brancaleone: İtalyanın Calabria bölgesinde bulunan bir yerleşim yeri, Paveseve Leone Ginzburg gibi hükümet karşıtı İtalyanların sürgün yeri olarak tanınmıştır. 
Bir gün bana intihar etmiş bir emlak yöneticisinden söz ederken, beş y1 önce kızını yitirdiğini, o zamandan beri çok değiştiğini, bu olayın onu 'için için yediğini’ söylemişlerdi. Bundan daha uygun bir sözcük bulunamaz. Düşünmeye başlamak, kendini için için yemeye başlamaktır. Bu başlangıçlarda toplumun fazla bir etkisi yoktur. Kurt insanın yüreğindedir. Yürekte aramak gerekir onu. (1997: 22)

Pavese'nin 1935 yılında yazmaya başladığı, ölümünden (27 Ağustos 1950) sekiz gün öncesine kadar yazmaya devam ettiği ve ölümünden sonra 1952 yllında yayınlanan günlüğünde, intihar olgusu oldukça geniş bir yer tutmaktadır. Ancak, intihar olgusu Pavese'nin sadece günlüğünde değil, diğer eserlerinde de göze çarpar. Örneğin, Tra donne sole adlı eserinde ana karakter Rosetta, tüm hikâye boyunca intihar etmeye çalışır, bir türlü beceremez ve ancak hikâyenin sonunda bu amacında başarılı olur: İlginç bir şekilde Rosetta, Pavese'nin intiharını hatırlatır bir şekilde, uyku hapları ile intihar girişiminde bulunur ve yaşama bilinçli bir şekilde veda eder. Rosetta'nın ruh halini ve hayata ilişkin tutumunu şu satırlardan okumak mümkündür:

Rosetta şaşırdı, o sabah otele niçin gittiğini kendinin bile bilmediğini söyledi. [...] Kaç zamandır gecelerden tiksiniyormuş, bir günü daha tamamlamış olmak, sıkıntılarıla baş başa kalmak, yatağa uzanıp sabahın olmasını beklemek dayanılmaz geliyormuş. Oysa o gece sona ermek üzereymiş. Ama uyku tutmayıp da odada dolaşmaya başlayınca geceyi, o gece tanık olduğu bir sürü saçmalı̆ğ düşünüp yine tek başına kaldığını, elinden bir şey gelmediğini görünce yavaş yavaş umutsuzluğa düşmüş ve çantasında da uyku ilacı olduğu için... (1998: 85)

Rosetta'nın kişiliğinde Pavese, yalnızlık öğesini belirginleştirir ve onu intihar ile bağdaştırır. Rosetta, bir nevi, 20. yüzyılda modernleşme ile birlikte maruz kaldığı kalabalıklar içinde yalnızlık yaşayan, karakter itibariyle ayrışmış, amaçsız ve savunmasız durumda olan bireyin bir temsilidir. Pavese bu durum tespitini kendi aynası olarak görülebilecek Rosetta üzerinde şu sözlerle anlatır:

Rosetta Mola saf bir kızdı, ama her şeyi ciddiye almıştı. Durduk yerde canına kıymaya kalkıştğ̆ doğruydu. Momina’ya duyduğu aptalca sevgi ya da başka bir sıkıntı canına kıyması için bir gerekçe olamazdı. Yalnız kalmak istiyordu, kalabalıktan kaçmak istiyordu; oysa o çevrede yalnız kalınamazdı, yalnız kalabilmenin tek yolu varlı̆̆ını ortadan kaldırmakt1. (1998: 94)

İntihar deneyiminin toplum üzerindeki yarattığı etkiyi ve toplumun birey üzerindeki etkisini derinlemesine inceleyen Pavese, Rosetta aracilığ1 ile toplumun dışlanmış bireye, diğer bir deyişle intihara kalkışan bireye bakışını ve onu küçümsemesini aktarır. Toplumun davranışı bireyin iyiliği değil, toplum normlarının zarar görmemesi ve kendi merakını tatmin etme anlayışı üzerine kuruludur. Pavese bu normları eleştirirken Rosetta'nın deneyiminden faydalanır: "Bir şeyler dedim, yanında annesiyle doktorun olduğunu söyledim. 'Roset- 
ta nasıldı onu söyle', dedi Monina öfkeyle. 'Bir yabancıda nasıl bir etki uyandırıyordu. Sen yabancı sayılırsın o gece. İğrenç miydi? Çırpınıyor muydu, bir başkası mı olmuştu? Ölünce nasıl oluyoruz?' Ölmek istiyordu o da” (1998: 62). Pavese'nin 1948 yılında kaleme aldığı, ölümünden bir yıl önce yayınlanan ve La bella estate (Güzel Yaz) ve Tra donne sole (Yalnız Kadınlar Arasında) ile bir üçleme oluşturan Il diavolo sulle colline (Tepelerdeki Şeytan) adlı eserde de intihar olgusu göze çarpar. Yazar, II. Dünya Savaşı'nın yarattığ 1 travmadan kurtulmak üzere, kırsal bölgelere çekilen ve kendileri dünyevi zevklere adamı̧̧ bir grup gencin hikâyesini anlattığı eserinde bir genç kızın, Rosalba'nın, intiharını anlatır. Bu intihar vakası ile Pavese'nin bu konu üzerinde, uzun süre boyunca ve tüm ayrıntılarılyla düşünmüş olduğu görülür, zira genç kızın intiharı ile ilgili olarak şöyle yazar: "Gözü pek olmak gerekiyor, ancak dibe vurarak kurtulabilir insan” (2000: 121).

Yaratmış olduğu karakterlerin çoğunu ve neredeyse her bir kitabını intihar ile ilişkilendiren Pavese'yi ölüme götüren nedenler arasında, aşk hayatında yaşadı$\breve{g} 1$ hayal kırıklıkları, kadınlarla olan ilişkilerinde hissettiği yetersizlik duygusu, günlüğünde de açıkça görüldüğü şekilde saplantılı ve mazoşist bir hale gelmiş yalnızlık arzusu ile bir yazar olarak anlatabileceği her şeyi anlatmış olduğu ve yazacak hiçbir şeyi kalmamış, tükenmiş olabileceği endişesi sayılabilir (Finzi 1993: 21). Pavese, hayatındaki bu yetersizliklerden dolayı yaşamına bir anlam verme arayışındadır ve bu arayış ile ilgili düşüncelerini şu satırlarda dile getirir: "Bir adamın hayatında değer kazanmak amacıyla o adamı öldürmek düşünülebilir mi? Öyleyse kendi hayatında bir değer sahibi olmak için de insanın kendini öldürmesi düşünülebilir. İntiharın güçlüğü şurada: insanın ancak tutkuyu aşarak gerçekleştirebileceği tutkulu bir davranıştır intihar” (1973: 75).

Bir anlam arayışından ve tutkulardan bahseden Pavese'nin intiharı, dikkat çekmek ve ün kazanmak için yapılmış bir eylem değildir. Pavese, Dialoghi con Leucò (Leuko ile Söyleşiler) adlı kitabının ilk sayfasına karaladığı intihar notunda "Herkesi affediyor, herkesten af diliyorum. Tamam mı? Arkamdan çok dedikodu yapmayınız" (Finzi 1993: 21) diye yazmaktadır. Bu çerçevede ele alındığında, Pavese'nin intiharı aciz bir haykırış ya da bir ilgi çekme çığlığı değil, sessizlik içinde gerçekleşen bir eylemdir (Ermumcu 1980: 60). Onun için intihar, yaşamı̧ olduğu hayatı ve benliğinde hissettiği duyguları aktarmak için seçtiği sade ve etkili bir yoldur.

\section{Özlü'de Svevo ve Pavese Etkisi: İntihar}

1943 yılında Kütahya'nın Simav ilçesinde dünyaya gelen Özlü, 1986 yılında İsviçre'nin Zürih kentinde hayata gözlerini yumar. Yazmış olduğu hikâyeler, romanlar ve Almanca'dan yapmış olduğu çeviriler ile adını duyuran Özlü'nün Yaşamın Ucuna Yolculuk adını taşıyan eseri, Svevo ve Pavese ile kurmuş olduğu 
fikir ve duygu bağını gözler önüne sermektedir: Özlü, Pavese ve Svevo'nun izlerinin peşinde koştuğu bir yolculuk içerisinde bulur kendisini.

Özlü’nün okuyucusunda yaratmak istediği duygu, Svevo ve Pavese gibi insan duygu ile düşüncelerini derinlemesine anlatmayı başarabilmiş yazarların kafalarının içlerine girmek, diğer bir deyişle, bu yazarların bilinç akışlarını yakalamaya çalışmaktır. Bu bağlamda, Özlü, okuyucuya kendi zihninin kapılarını açmakta ve bu kapılardan giriş için ipuçları sunmaktadır.

Özlü'nün ruh yapısını etkileyerek, onu Pavese ile Svevo'nun duygusal durumuna yaklaştıran öğeler, genel itibarıyla kişisel ve topumsal olarak ikiye ayrılabilir: ilkinde, Özlünün yaşamış olduğu hastalıklar sonucunda kliniğe kapatılması ve tedavi görmesiyle birlikte fiziksel olarak da güçsüzleşmesi ve kendini daha yalnız hissetmeye başlaması ön plana çıkar: tıpkı zayıf ve hastalıklı bir bedenin Pavese'nin yalnızlık düşüncelerine zemin oluşturması gibi. İkinci olarak ise, toplumsal nedenler Özlü'nün düşünce yapısını oldukça etkiler: Sosyal ve siyasal açıdan zor günler yaşayan ve oldukça hızlı bir değişim geçiren bir toplumun bireyi olarak Özlü bu hızlı değişime ayak uyduramaz; Kendi değer yargılarının ve fikirlerinin kabul görmemesi korkusu, toplum ve Özlü arasında bir çekingenlik ilişkisinin doğmasına neden olur. Özlü, Svevo'nun karakteri Alfonso Nitti gibi, kendini toplumdan kopmuş halde, başka bir arayışın içinde bulur.

I. Dünya Savaşı'nın ardından, ilk gençlik yılları ve II. Dünya Savaşı'nın getirdiği zorluklar ile her iki savaşın yıkımına tanıklık etmiş olan Pavese'nin ruhunda duyumsadığ bir topluma ayak uydurmanın zorluklarını yaşayan, kendini toplumdan farklı gören ve ayrı tutan Özlü de ruhunda duyumsar. Bu yalnızlığı, yazmış olduğu ilk roman olan ve kendi çocukluk çağına dönüş mitosuna yer verdiği Çocukluğun Soğuk Geceleri adlı eserinde şu cümlelerle açıllar: "Ölüm düşüncesi izliyor beni. Gece gündüz kendimi öldürmeyi düşünüyorum. Bunun belli bir nedeni yok. Yaşansa da olur yaşanmasa da. Bir kaygı yalnız. Beni, kendimi öldürmeyi denemeye iten bir kayg”" (2000: 12).

Pavese ölüm ile ilgili ardı arkası kesilmez bir bekleyiş içindedir, tıpkı Svevo'nun yarattığ1 Alfonso Nitti karakterinin yaşadığı gelgitlerde olduğu gibi. Savaşın yarattığı travmanın etkisiyle birey ve toplum arasında bir çatlak oluşur. Svevo'da ve Pavese'de bu çatlağın edebiyata yansımaları, karakterlerin toplumdan kopuşu ve topluma uyum sağlayamamaları olarak yansımıştır. Benzer şekilde Özlü de, yaşadığı topluma ayak uyduramamış, kendisini çevreleyen yapı ile arasında mesafeler oluşmasına engel olamamıştır. İntihar düşüncesi ise, toplumdan ayrılma ve kopuşun beraberinde gelen bir olgudur: "Bizi saran s1caklığın. Soğuyan gecelerin. Ve geceleri bürüyen yıldızların. Dolunayla birlikte uykusuz kalınan gecelerin soluk, sisli sabahlarında ölümü bekleyen insanların. (Ölüm de bir günlük olay değil mi?)” (2000: 65). 
Toplum ve birey arasında doldurulması zor boşluklar yaratan intihar, beraberinde yalnızlık duygusunu da getirir. Pavese'nin Il mestiere di vivere (Yaşama Uğraşı) adlı günlük olarak kaleme alınmış eserinde intihar düşüncesi ile yalnızlık düşüncesi birbirlerine koşut yapıdadırlar. Pavese, yalnızlığ 1 için: "Yalnız kalmamak için tüm gece aynanın karşısında oturdum" (1973: 68) diye yazar. Bu yalnızlı̆̆ın yarattığı iç sıkıntısını Özlü, Pavese'nin intiharı (Tra donne soléde yaratmış olduğu Rosetta karakteri) ile ilişkilendirerek anlatır:

Karanlık bir gecenin geç vaktinde kalkıyorum. Herkes her geceki uykusunu uyuyor. Ev soğuk. Çok sessiz davranmaya özen gösteriyorum. Günlerdir biriktirdiğim ilaçları avuç avuç yutuyorum. Kusmamak için üzerine reçelli ekmek yiyorum. Genç bir kızım. Ölü gövdemin güzel görünmesi için gün boyu hazırlık yapıyorum. Sanki güzel bir ölü gövdeyle öç almak istediğim insanlar var. (2000: 12)

Ancak ölüm ve intihar, tıpkı Svevo ve Pavese gibi, Özlü için de Jung’un söz ettiği şekliyle bir kaçış ya da yeni bir başlangıç umudu değildir. Daha ziyade, Durkheim'ın da bahsetmiş olduğu gibi, sosyal bir olgudur. Özlü, Durkheim'ın belirttiği gibi, intiharın sonuçlarının bilincindedir. İntiharı bir son, bir bitiş olarak algılamaz; onun için intihar pek çok yapraktan oluşan bir kitabın sayfalarından sadece biridir. Bu noktada, Menninger'in kronik intihar olgusuyla koşutluk gösterir, sürekli bir intihar düşüncesinin peşinden sürüklenir durur. Her bir insanı ve yaşamı bu kitabın bir sayfası sayar; bir sayfa okunup bittiğinde, değersizleşmediğini ve sona ermediğini, kendinden öncekini hatırlattığ1$\mathrm{n} 1$, kendisinden sonra gelecek olanı ise müjdelediğini düşünür: "Yeryüzünün öyküleri sonsuzdur. Birini anlatmayı bitirdiğinde, bir başka yerde, bir başkası anlatmaya başlar. [...] Yeryüzünün intiharları sonsuzdur. Biri, bir yerde intihar ettiğinde, bir başkası intihar etmeye hazırlanıyordur. Biri ölmeye başladığında, bir başka yerde yaşama başliyordur diğeri” (Özlü 2005: 108).

\section{Sonuç}

Hem Pavese'nin hem de Svevo'nun eserlerinde yaratmış oldukları karakterler, kendilerini ait hissedebilecekleri bir yer ararlar: zira sözü edilen bu karakterler kendilerini içinde yaşadıkları zamana, mekâna ve topluma ait hissetmemektedirler. Sosyalleşmenin hızı, sosyolojik yapının değişmesi ile şekillenen bu arayışta karakterlerin, daha geniş çerçevede ise yazarların, psikolojisi oldukça önem kazanır. Yazarlar da karakterleri ile birlikte bir öz ve kimlik arayışına doğru yolculuğa çıkarlar.

Özlü’nün Yaşamın Ucuna Yolculuk ve Çocukluğun Soğuk Geceleri adlı eserlerinde yaptığı yolculuklar, tıpkı Pavese ve Svevo'da olduğu gibi, özünde birer anlam arayışıdırlar. Lukacs'ın belirttiği şekilde karakterin sorunsallı̆̆ını yansıtırlar. Pavese'nin ve Svevo'nun yaşadıkları savaş dolu yıllar, gerçekçiliğin önemini 
daha da arttırmaktadır; yıpranma ve yok oluşlar karşısında, hayal dünyasının dışına çıkma isteği, insanların acılarını ve halkların çilelerini edebiyat aracılığıyla anlatma isteği ön plana çıkmaktadır. Bu arzu ile birlikte insanın yeryüzündeki arayışının sonuna ulaşmak için bir yol belirir. Bu yol için Özlü şunları yazmaktadır: "-Evet. Ölüm. İnsanın tanrısına kavuşması. O en kutsal an... Tanrıya kavuşulan en kutsal an. Varoluşun tek gerçek anı... Ölüm. Tanrıyla birleşme" (2000: 20).

Görüldüğü üzere, İtalyan edebiyatının önemli isimlerinden olan Pavese, Svevo ve Türk edebiyatının son dönem yazarlarından Özlü’nün adı geçen eserlerinde intihar olgusu önemli bir rol oynamaktadır. Son olarak varılan noktada, Özlü kendisinin fikir mimarları olarak işaret ettiği Svevo ve Pavese ile benzer sosyolojik ve psikolojik tutumları benimsemekte, aynı nitelikteki sorunsallar ile mücadele etmekte ve kendi hayatına ilişkin bir arayışın peşi sıra koşmaktadır. Nihayetinde, denilebilir ki, Özlü’nün Yaşamın Ucuna Yolculuk ve Çocukluğun Soğuk Geceleri adlı eserlerinde yer verdiği intihar olgusunun kökenleri, İtalyan yazarlar Svevo ve Pavese'ye uzanmaktadır: Söz konusu olan yalnızca ruhsal bir yakınlaşma değildir, üslup olarak da Özlü, Svevo'nun bilinç akışı ile Pavese'nin gerçekçi ve yalın anlatımını benimsemektedir. Bir bütün olarak değerlendirildiğinde, her üç yazarın da insan psikolojisine ve intihara büyük önem verdik38 leri açıkça görülmektedir. 


\section{Kaynaklar}

Balamir, Ebru (2013). “İtalyan Şair-Yazar Cesare Pavese'nin Yapıtlarında Üslup Özellikleri”, 13.Uluslararası Dil, Yazın ve Deyişbilim Sempozyumu Bildiri Kitabı, Kars: Kafkas Üniversitesi Yayınları.

Barry, Peter (2002). Beginning Theory, An Introduction to Literary and Cultural Theory, Manchester: Manchester University Press.

Calvino, Italo (2008). Klasikleri Neden Okumal, Çev. Kemal Atakay, İstanbul: Yapı Kredi Yayınları.

Camus, Albert (1997). Sisifos Söyleni, Çev. Tahsin Yücel, İstanbul: Can Yayınları.

Durkheim, Emile (1986). İntihar, Çev. Özer Ozankaya, Ankara: Türk Tarih Kurumu Yayınları.

Ermumcu, Ziya (1980). Cesare Pavese’nin Şiirlerinde İslenen Temalar, Ankara: Ankara Üniversitesi Yayınları.

Finzi, Gilberto (1993). Come leggere "La luna e ifalò di Cesare Pavese, Milano: Mursia Editore.

Freud, Sigmund (1993). “Yas ve Melankoli”, Çev. R. Uslu ve O. E. Berksun, Kriz 1 (2). Giuseppe, Petronio (2000). Racconto del novecento letterario in Italia (1890-1940), Milano: Mondadori.

Lukács, Georg (2011). Roman Kuramı, Çev. Cem Soydemir, İstanbul: Metis Yayınları. Manacora, Giuliano (1977). Storia della letteratura italiana contemporanea (19401975), Roma: Editori Riuniti.

Meloor, Ken (1979). "Suicide: Being Killed, Killing anda Dying", Australasian Journal of Transactional Analysis 1 (1).

Minios, Georges (2008). İntiharın Tarihi, Çev. Nermin Acar, Ankara: Dost Yayınevi. Özlü, Tezer (2000). Çocukluğun Soğuk Geceleri, İstanbul: Yapı Kredi Yayınları.

- (2000). Yaşamın Ucuna Yolculuk, İstanbul: Yapı Kredi Yayınları.

Pavese, Cesare (1973). Yaşama Uğraşı, Çev. Cevat Çapan, İstanbul: E Yayınları.

- (1997). Ay ve Şenlik Ateşleri, Çev. Rekin Teksoy, İstanbul: Can Yayınları.

- (1998). Yalnız Kadınlar Arasında, Çev. Rekin Teksoy, İstanbul: Can Yayınları.

— (2000). Tepelerdeki Şeytan, Çev. Egemen Berköz, İstanbul: Can Yayınları.

Pazzaglia, Mario (1988). Antologia della letteratura italiana III, Bologna: Zanichelli Editore.

Salinari, C. ve C. Ricci (1993). Storia della letteratura italiana III-Novecento, RomaBari: Editori Laterza.

Svevo, Italo (2010). Una vita, Roma: Newton Compton Editore.

The Encyclopedia of Suicide (2003). Ed. G. Evans ve N. L. Farberow, New York: Facts on File. 


\section{ABSTRACT \\ The Concept of Suicide in Cesare Pavese, Italo Svevo and Tezer Özlü}

The concept of suicide has an important place in Italo Svevo and Cesare Pavese's works, prominent writers of the $20^{\text {th }}$ century world and Italian literature. Suicide is one of the most decisive aspect of the characters created by Svevo and Pavese. Suicide has been a descriptive element of the cracks that appear in individual and social relations as not only a psychological situation, but also a sociological concept. Traumas experienced by Svevo and Pavese both in the familial and communal level, have some parallelism on the concept of suicide featured by these authors in their literary works. Tezer Özlü, whose literary works belong to second half of the $20^{\text {th }}$ century, has similar aspects regarding to the concept of suicide with the authors mentioned above. This article aims to examine these parallels among Svevo, Pavese and Özlü with respect to the concept of suicide, and to uncover the similarities among them.

Keywords: Suicide, Italian literature, Italo Svevo, Cesare Pavese, Turkish literature, Tezer Özlü 